\title{
Capital Markets Union in Europe: Why Other Unions Must Lead the Way
}

\author{
Viral V. Acharya a and Sascha STeffen ${ }^{b}$
}

JEL-Classification: G01, G15, F34

Keywords: Capital Markets Union, financial market integration, sovereign risk

\section{SUMMARY}

Government bond markets in the Euro Area are highly fragmented causing further fragmentation in bond and equity markets. Capital Markets Union with fully integrated capital markets across member countries can only work when the status of member country sovereign bonds as risk-free assets is restored. Banking Union and fiscal union are both required for this outcome. However, the Banking Union remains an unfinished project without an European deposit insurance framework and there is little consensus at the moment for a fiscal union in the Euro Area. It appears thus that the fate of the Capital Markets Union solely rests with the European Central Bank in the near to medium term.

a C.V. Starr Professor of Economics, Department of Finance, New York University, Stern School of Business, 44 West 4th St., New York, NY 10012, email:vacharya@stern.nyu.edu, phone: +1 (212) 9980354 fax: +1 (212) 995 4256. Acharya is also a Research Affiliate of the CEPR and a Research Associate in Corporate Finance at the NBER.

b University of Mannheim, Area of Banking, Finance and Insurance, and Centre for European Economic Research (ZEW), L7, 1, 68161 Mannheim, Germany), email: steffen@zew.de, phone: +49 (0)621 1235 140, fax: +49 (0)621 1235223 . 


\section{Market Segmentation in Sovereign Bond Markets}

Starting with the financial crisis in 2008-2009, European capital markets became increasingly fragmented. This process accelerated with the deepening of the sovereign debt crisis in Europe in 2011. A notable example is the government bond market, which is not only the largest capital market in Europe but is also critical for the functioning of other capital markets: Government bonds used to be the safe assets needed to facilitate transactions and price securities.

However, the massive public sector debt overhang - that was to some extent caused by financial sector bailouts and recovery programs - sparked doubts about the ability of some countries to repay their debt. Yield spreads of peripheral countries (Greece, Italy, Ireland, Portugal and Spain, GIIPS henceforward) to German federal bonds (bunds) widened and investors retrenched to their home market. The empirical literature has documented different reasons for this "home bias": (1) moral hazard of weak GIIPS banks to buy domestic government bonds (Acharya and StefFen, 2015), (2) financial repression, where governments pressure domestic banks to buy their debt during turbulent economic times (BECKER and Ivashina, 2014); and (3) banks as buyer of last resorts during crises, where weak banks buy domestic sovereign debt positively correlated with other sources of revenue (Crosignani, 2015). ${ }^{1}$ Sovereign debt became entrenched to banks' balance sheets causing large losses when sovereign debt deteriorated in 2011 and the first half of 2012. ${ }^{2}$

Figure 1 strikingly shows the increase in home bias over time. We plot Italian and Spanish banks' domestic government bond holdings relative to banks' total assets using data obtained from the European Central Bank (ECB) that include all monetary financial institutions in both countries. At the same time, yields on Italian and Spanish sovereign bonds were substantially increasing (Figure 2). They diverged further from, e. g., German bunds, whose yields were even decreasing due to elevated demand when investors were scrambling for high-quality assets in a "flight-to-quality".

1 In a German setting, Buch et al. (2014) show that weakly capitalized German banks also hold more domestic sovereign bonds.

2 Short-term investors also ran on banks with large exposures to sovereign debt (ACHARYA, PIerRET and STEFFen, 2016). 
Figure 1: Home Bias

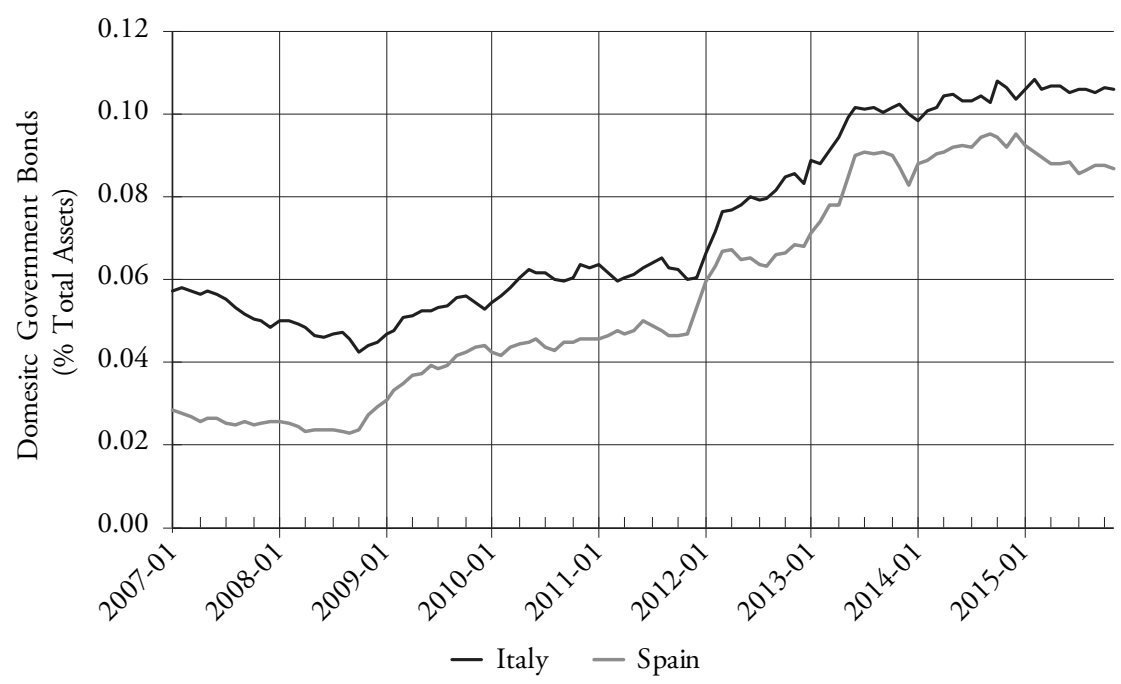

Source: European Central Bank

Figure 2: Sovereign Bond Yields

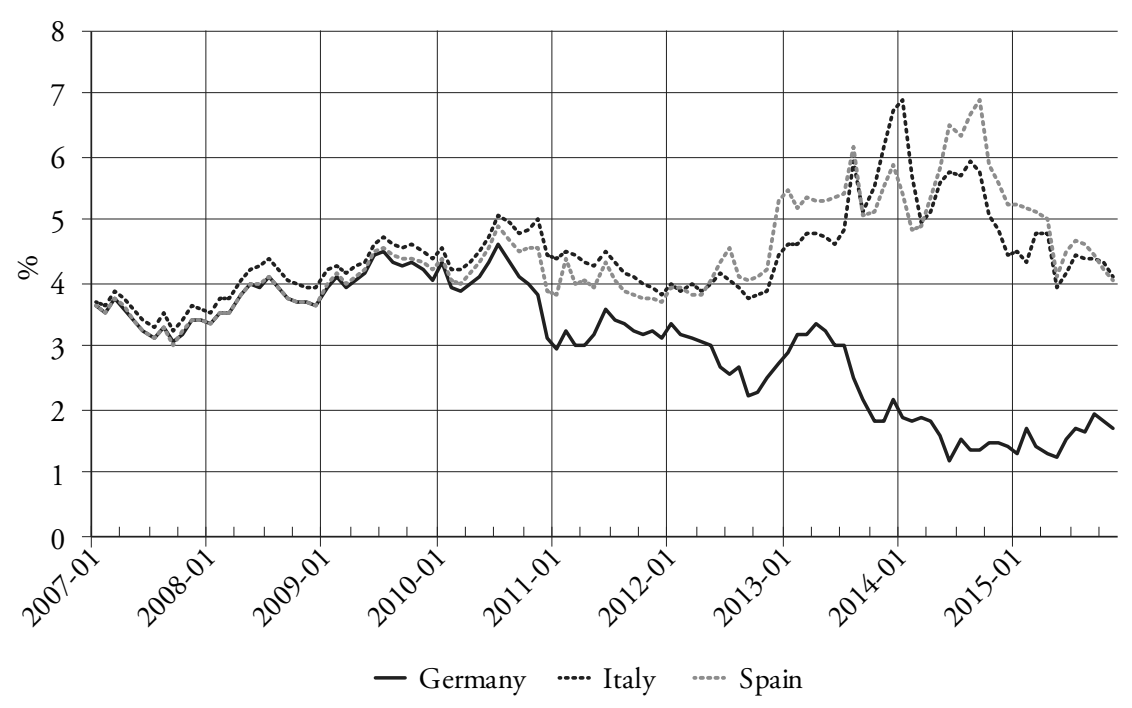

Source: Datastream 


\section{Spillovers into Other Capital Markets}

The problems in the government bond market eventually spilled over into other capital markets. Sovereign default risk as well as concerns regarding the stability of the Euro Area increased home bias in other capital markets in that there emerged substantial country factors in the pricing of equity and corporate bond markets. The elevated sovereign risk increased the cost of capital of peripheral country firms that continued to diverge from the cost of capital of similar core European companies.

To illustrate this, we show the emergence of the spread differences on newly issued loans in Europe (Figure 3). We obtain data from the ECB and plot the spreads on new loans issued to non-financial firms in GIIPS countries and Cyprus (GIIPS+C) relative to spreads paid by German firms since January 2007 in the first graph. The second graph shows the loan spread differential as the difference of spreads paid by firms in GIIPS countries and Cyprus and Germany. Both figures suggest that loan spreads in peripheral countries started to increase relative to Germany at the end of 2009 and diverged even further in the fall of 2011 and the first half of 2012 when the Euro crisis deepened. ${ }^{3}$

Almeida et al. (2016) also provide evidence how sovereign impairments affect corporate bond markets. In particular, they show that highly rated firms (those that are better rated compared with their sovereigns) are more affected by a sovereign rating downgrade compared to firms that are already lower rated than their domestic sovereign. That is, they experience a larger increase in cost of debt capital compared to lower rated firms. Moreover, and given the elevated risk of being downgraded themselves, highly rated firms reduce debt issuances and leverage and increase issuing equity. However, given adverse market conditions around sovereign downgrades, an increase in equity issuance cannot offset the reduction in debt financing resulting in a reduction in investment activity.

A functioning Capital Markets Union (CMU) should not feature such spillovers and to ensure that, it needs a level-playing field in the holding and transacting of debt and equity securities by market participants in different countries. That is, a CMU with fully integrated capital markets can only work when the

3 The increase in loan spreads is directly linked to the increase in funding costs of the banking sector in the peripheral countries. In its quarterly report about the Euro Area, the European Commission showed that funding costs of peripheral banks were two to four times as high compared to funding costs of German banks in 2011 and the first half of 2012 (EC, 2015). ACHARYA et al. (2015) also show that low-risk banks reduced loan spreads of customers relative to high-risk banks after the ECB implemented the full allotment principle in October 2008. 
Figure 3: Loan Spread Difference

Interest Rates (New Loans)

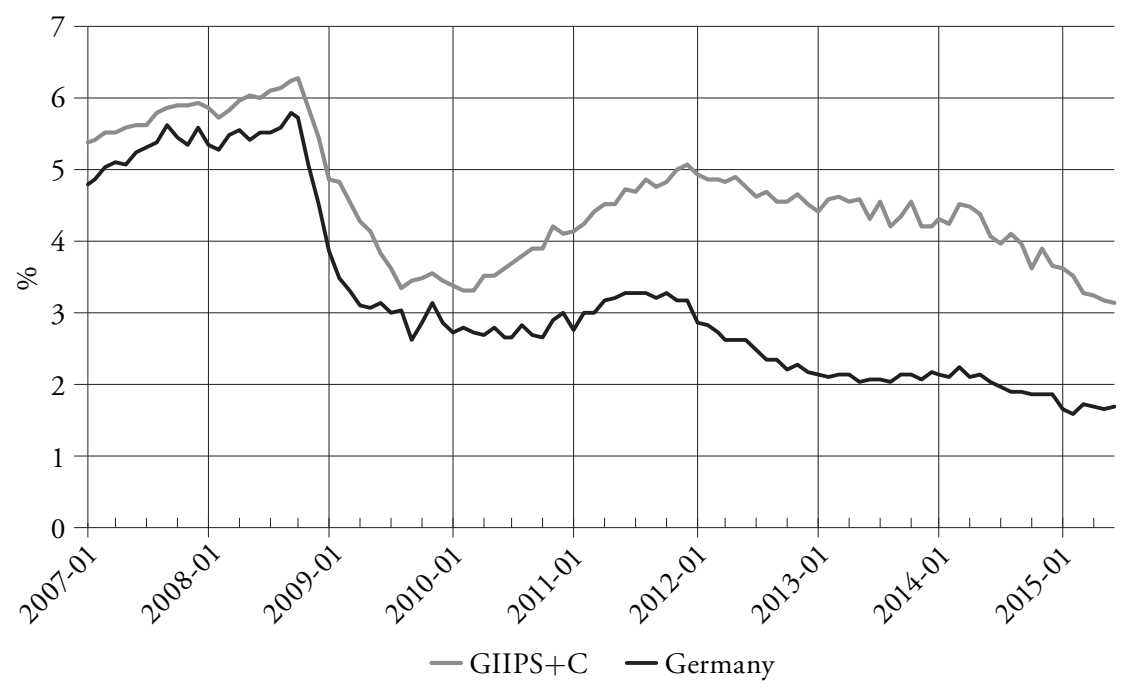

Spread Differential

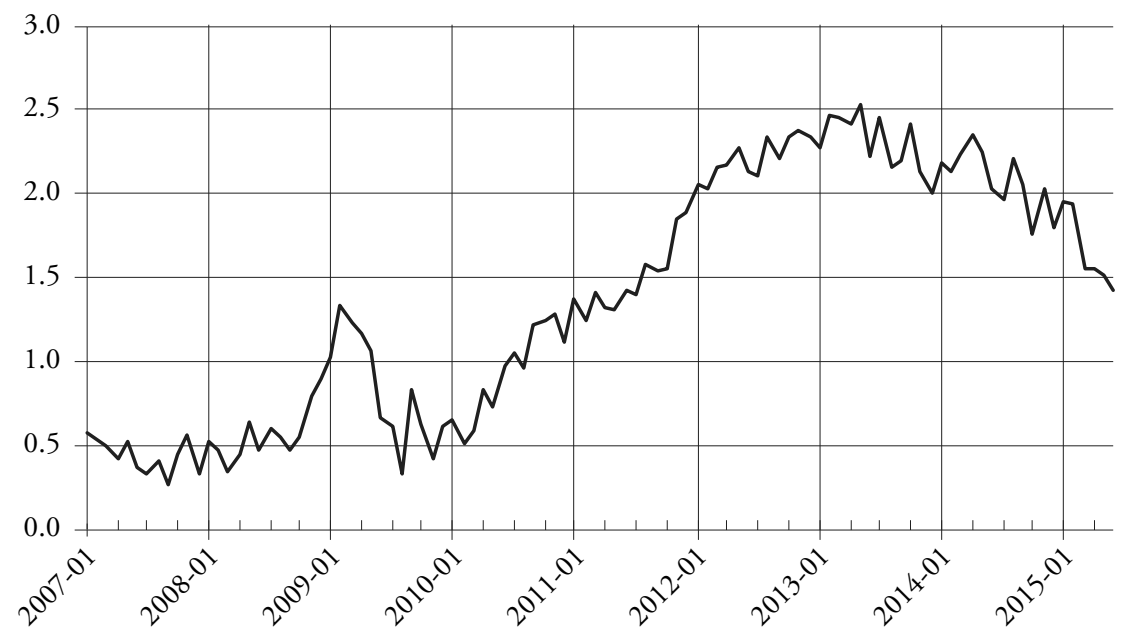

Source: European Central Bank 
status of sovereign bonds as a risk-free asset is restored and the risk-free rate across Euro Area countries is equalized.

\section{The Importance of Other Unions to Capital Markets}

\section{a. The Banking Union}

European leaders have started a series of reforms that will reshape the financial architecture of the Eurozone and that are crucial for the CMU to work. The "Banking Union" (BU) that has been agreed on in June 2012 and started with the introduction of the Single Supervisory Mechanism (SSM) in November 2014 was an important step in this direction. BU consists of three pillars: (1) the SSM, (2) the Single Resolution Mechanism (SRM) and (3) a European Deposit Insurance Scheme.

The "traditional view of banking" is that banks' liabilities are effectively riskfree (and this, in fact, was our understanding until the global financial crisis started in August 2007). The reason is three-fold. First, government bonds are risk-free and banks are the largest owner of domestic sovereign debt. Second, depositors are insured preventing bank runs. Third, banking regulation ensures that banks are adequately capitalized. These factors contributed to the development of a European interbank market, in which banks lend to each other, shortterm, without any collateral. That allowed the ECB to conduct its monetary policy at a single interbank market rate. ${ }^{4}$

The financial crisis revealed the shortcomings of this concept in the context of an (incomplete) monetary union. Government bonds are not risk-free across the Eurozone. As banks' balance sheets were bloated with government bonds, the increase in sovereign risk also further increased solvency risk of Eurozone banks (Acharya, Drechsler and Schnabl, 2014). Moreover, regulation was not harmonized across Euro Area countries. There were differences in deposit insurance frameworks causing deposit flights from peripheral to core European banks. Similarly, there were differences in accounting standards and banking regulation across countries. Bank insolvency was a national problem and regulators were inclined to exercise leniency to avoid a collapse of its banking system facilitating the rise of zombie banks and firms in the peripheral countries.

4 The ECB only needs to make sure that banks have sufficient liquidity to meet their reserve requirements on aggregate, and the interbank market ensures that banks that need liquidity can borrow from banks that have abundant liquidity. 
The BU is supposed to address these shortcomings. All banks are directly or indirectly under the same supervision using the same set of rules and regulation (SSM). A banking collapse should not become a national (i. e. sovereign) problem that increases sovereign risk because of national government bails-outs (SRM). The BU should also reduce sovereign-bank linkages and forbearance by national regulators. In particular, BU can help ensure that banks in different countries are all adequately capitalized and do not have incentives to entrench balance-sheets with risky domestic government debt, in turn imposing discipline on domestic fiscal authorities. In other words, BU is crucial for CMU to work.

\section{b. The Fiscal Union}

CMU also needs a fiscal union that completes the European monetary union. While one aspect of fiscal union is budgetary discipline and eventually ceding some sovereignty to a European authority, another important aspect is the expost risk-sharing arrangement across Euro Area countries when a member country is in distress. ${ }^{5}$

The problems without having risk-sharing arrangements in place became obvious in 2011 and 2012, when yields on GIIPS sovereign bonds increased because investors were concerned with the solvency of the governments and whether countries remain part of the monetary union. The private sector involvement (PSI) in the attempt to solve the Greek debt crisis and the eventual haircut of private investors by $53.5 \%$ intensified concerns that investors on Eurozone sovereign bonds would not be repaid in full even when other countries supported these bonds, which segmented sovereign bond markets even further. The increase in sovereign bond yields amplified solvency concerns of the sovereigns, and, in absence of a BU, also the solvency risk of the banking system, which reinforced the solvency risk of the sovereign.

In turn, country specific factors began to have a substantial impact on both equity and bond markets and, consequently, on real economic activity in these

5 An analysis different from ours suggests an alternative that, according to the authors, does not require a fiscal union. Brunnermeier et al. (2011) propose the use of "European Safe Bonds" (ESBies). ESBies pool existing sovereign bonds and create a risk-free security that can be used as collateral in private repo transactions as well as by the ECB. However, such as securitization structure requires a risky junior tranche and might even additionally require a credit enhancement (i.e. a guarantee) that is provided by paid-in capital from the different sovereigns. The junior tranche has to be purchased by investors outside the banking system. It is unclear, however, how many investors are willing to buy the junior tranche. That is, ESBies will likely depend on further public sharing as well. 
countries. A fiscal union is therefore crucial to ensure that capital markets are not adversely affected by individual country-level risks. Moreover, a fiscal union may not suffice by itself as banks in different countries also need to play on a level-playing field in capital markets. Taken together, the BU and fiscal union are both necessary to build a functioning CMU.

\section{The Role of the ECB: Making-up for a Lack of Political Union}

The ECB is at the center stage of the Eurozone crisis, particularly because of the lack of commitment of national governments with respect to further integration and to address the above mentioned shortcomings of the financial architecture of the monetary union.

Currently, the BU also remains an unfinished project. Several core-European countries have refused to implement the common deposit insurance framework. Limited committed funding to deal with bank insolvencies also compromises the requirement that national governments and taxpayers are insulated (ex post) from banking collapse in the future. In other words, the BU has not been able to fully address the sovereign-bank "doom loop" (see Figure 1). ${ }^{6}$ However, the new role of the ECB as single regulator of the European banking system is an important first step into this direction.

The ECB had to step in as "lender of last resort" (LOLR) on different occasions, notably, for the first time, implementing the full allotment of liquidity in October 2008, and with the 3-year Long-Term-Refinancing-Operations (LTRO) in December 2011 and February 2012. The ECB was able to reduce funding liquidity risk as LOLR (Acharya et al., 2015; Acharya, Pierret and Steffen, 2015). However, the LTROs further distorted government bond markets by giving banks' liquidity to increase their domestic sovereign bond holdings that further segmented the government bond market. At the same time, the ECB reduced the collateral requirement for central bank repo transaction including also low-rated government bonds.

6 Moreover, the BU was implemented to deal with future crises, not to mutualize the bad (legacy) assets that banks have accumulated during the pre-crisis period. The ECB has performed a comprehensive assessment ahead of the start of the SSM, in which it analyzed banks' portfolios using a harmonized set of rules such that any capital shortfall can be addressed by each country individually and all banks are adequately capitalized at the start of the ECB. Whether the ECB has been successful in recapitalizing the Euro Area banking system can be questioned (compare, e.g. Acharya and Steffen (2014a, b)). 
After European leaders agreed to the BU, ECB President Mario Draghi declared on July 26, 2012, during a conference in London that he will do "whatever it takes" to preserve the euro. The ECB announced outright purchases of sovereign debt in secondary bond markets and the parameters of the OMT program in the following months. A key provision requires countries to participate in a financial support program from the European Stability Mechanism (ESM) and to comply with the required reform efforts. Instead of providing liquidity to the banking system, the ECB announced to purchase assets directly acting as a "Buyer of Last Resort" (BOLR). Sovereign bond yields of peripheral countries compressed substantially following the announcement because of a reduction in sovereign default risk (e.g., because of the conditionality and required reform efforts) as well as a reduction in segmentation and redenomination risk (KRISHNAMURThy, Nagel and Vissing-Jorgensen, 2015).

Lower sovereign bond yields also reduced the risk of the banking system. In fact, it implicitly recapitalized the banks holding massive amounts of sovereign bonds and reduced banks' incentives to hold sovereign debt potentially reducing the sovereign-bank loop (Acharya, Pierret and Steffen, 2016). Figure 1 suggests that the OMT program did decelerate the increase in home-bias but did not reverse it. However, foreign investors appear to have started purchasing peripheral sovereign bonds suggesting that markets have become more integrated.

While the national governments were hesitant to push for further integration, the ECB "artificially" created two aspects important in a fiscal union with the OMT program. First, distressed countries cede some sovereignty when applying for ESM financial assistance. Second, when purchasing the bonds, the ECB effectively introduces risk-sharing among Euro Area countries since in the event of the ECB making losses on these bonds, it will likely be recapitalized by stronger countries in the Eurozone. The convergence of sovereign yields in the Eurozone suggests that the ECB effectively moved closer to making government bonds a "safe" asset. In turn, this has helped restore conditions for a CMU in the Eurozone.

\section{Conclusion}

A functioning Capital Markets Union needs a Banking Union and a fiscal union to work. First steps have been made with the start of the Banking Union, the implementation of the Single Supervisory Mechanism and the Single Resolution Mechanism. European leaders, however, do not seem to have the political will to enforce more integration both with respect to completing the deposit insurance 
part of the Banking Union and to pursuing fiscal union. In fact, arrangements such as the Private Sector Involvement created further segmentation.

The European Central Bank (arguably within the mandate to pursue its monetary policy objective) introduced the Outright Monetary Transactions program which increased integration among Eurozone member countries. Sovereign yields in the Euro Area started to converge, an important step for Capital Markets Union. It is uncertain, however, whether this arrangement can be a viable, longterm solution, so that in the long run only completion of the Banking Union process and a movement towards fiscal union are likely to create a sustainable Capital Markets Union.

\section{References}

Acharya, V., I. Drechsler, and P. Schnabl (2014), "A Pyrrhic Victory? Bank Bailouts and Sovereign Credit Risk", Journal of Finance 69(6), pp. 2689-2739. Acharya, V., B. Imbierowicz, S. Steffen, and D. Teichmann (2015), "Does Lack of Financial Stability Impair the Transmission of Monetary Policy?", working paper.

Acharya, V., D. Pierret, and S. Steffen (2016), "Lender of Last Resort versus Buyer of Last Resort -The Impact of the European Central Bank Actions on the Bank-Sovereign Nexus", working paper.

Acharya, V., and S. Steffen (2014a), "Falling Short of Expectations - Stress Testing the Eurozone Banking System”, working paper, NYU Stern School of Business.

Acharya, V., and S. Steffen (2014b), "Benchmarking the European Central Bank's Asset Quality Review and Stress Test - A Tale of Two Leverage Ratios", NYU Stern School of Business.

Acharya, V., and S. Steffen (2015), “The 'Greatest' Carry Trade Ever? Understanding Eurozone Bank Risks”, Journal of Financial Economics 115(2), pp. 215-236.

Alemeida, H., I. Cunha, M.A. Ferreira, and F. Restrepo (2016), “The Real Effects of Credit Ratings: The Sovereign Ceiling Channel”, Journal of Finance (forthcoming).

7 The ECB is not an elected government and OMT has already been challenged in open court. 
Becker, B. and V. Ivashina (2015), "Financial Repression in the European Sovereign Debt Crisis", working paper.

Brunnermeier, M., L. Garicano, P. R. Lane, M. Pagano, R. Reis, T. Santos, D. Thesmar, S. Van Nieuwerburgh and D. Vayanos (2011), "European Safe Bonds (ESBies)", working paper.

Buch, C. M., M. Koetter, and J. Ohls (2014), „Banks and Sovereign Risk: A Granular View”, Deutsche Bundesbank Discussion Papers 29.

Crosignani, M. (2015), "Why Are Banks not Recapitalized During Crises?”, ONB Working Paper no. 203.

EC (2015), Quarterly Report on the Euro Area, Volume 14, No.4, European Commission, Directorate-General for Economic and Financial Affairs.

Krishnamurthy, A., S. Nagel, and A. Vissing-Jorgensen (2015), "ECB Policies Involving Government Bond Purchases: Impact and channels", working paper. 